\title{
Teaching, learning and ethical dilemmas: Lessons from Albert Camus
}

\author{
Peter Roberts \\ University of Canterbury
}

\begin{abstract}
Over the past half century, Albert Camus' story 'The Guest' has attracted a great deal of scholarly attention. 'The Guest' focuses on the ethical dilemmas faced by Daru, a school teacher in Algeria, and the two visitors he receives one day: Balducci, a gendarme, and an unnamed Arab prisoner. This paper addresses Camus' text from an educational point of view. The first section outlines the position taken by Daniel Muhlestein, who analyses 'The Guest' in the light of Louis Althusser's distinction between Repressive State Apparatuses (RSAs) and Ideological State Apparatuses (ISAs). The second section provides an alternative educational reading of the text - one based on the moral complexity of the three principal characters. It is argued that the ethical questions raised by 'The Guest' are similar to those faced by many teachers, and that this is a story worthy of continuing educational engagement.
\end{abstract}

\section{Introduction}

Of all the fictional works published by Albert Camus, his story 'The Guest' ('L’Hôte') is among the most pregnant with possibilities for multiple readings. This short text, included as one of six stories in the collection Exile and the Kingdom (Camus, 1991), has provided the focus for a great deal of scholarly attention over the past half century. It has, as one critic put it, attained 'canonical permanence' in Camus' corpus of published writings (Hurley, 1993, p. 79). From early on, commentators have acknowledged that, despite its brevity and apparently simple narrative structure, this is a 'subtle and difficult' story (Perrine, 1963). Rich with symbolism, with silences as significant as its utterances, this enigmatic tale invites deep philosophical reflection. 'The Guest' first appeared as a story in Atlantic Monthly in December 1957, and Exile and the Kingdom was published in early 1958 (Showalter, 1984, p. 5). Camus had been experimenting with new writing styles in the period leading up to the publication of Exile and the Kingdom (Todd, 2000, p. 350). His important novella, The Fall (Camus, 2000), had been published in 1956, and in 1957 Camus had been awarded the Nobel Prize for literature. The 'Exile' in the title of Exile and the Kingdom was, in the words of Camus's biographer Olivier Todd, intended to be 'historic, geographical and moral', while the 'Kingdom' was 'Paradise Lost, beyond suffering and self-denial' (Todd, 2000, p. 350).

'The Guest' focuses on the ethical dilemmas faced by a French Algerian school teacher, Daru, and the two unexpected visitors he receives one day: Balducci, a gendarme he has known for many years (who arrives on horseback), and an unnamed Arab prisoner (who has his hands bound, is tied to Balducci, and is on foot). Daru's schoolhouse is on a hillside overlooking a vast, deserted plateau about $20 \mathrm{~km}$ from Tinguit. Balducci informs Daru that he (Daru) will have to deliver the prisoner to police headquarters. Daru objects that this is not his job, but Balducci notes that 
'[t]hings are brewing' and there is 'talk of a forthcoming revolt' (p. 92). Daru asks what the Arab has done and is told he has killed his cousin. Expressing disgust at 'every bit of this' (p. 95), Daru declares that he will not hand the prisoner over. After some reflection, Balducci says he will not denounce Daru to the authorities but requests the latter's signature on the required form. Refusing to be seen out by Daru, Balducci departs on his own, leaving Daru alone with the Arab. Daru provides food for the prisoner, has a brief conversation with him, and shows him to his bed. Unable to sleep, Daru watches the Arab, who at one point rises from his bed, goes outside, and returns after a short interval. Later in the night, Daru thinks he hears footsteps around the schoolhouse, but tells himself he is only dreaming. The next morning, after breakfasting together, Daru and the prisoner set off on their journey. Upon reaching a level area of crumbly rocks, Daru identifies two possible directions. He gives a package of food and a thousand francs to the Arab and shows him the two different directions: one leading to the waiting police at Tinguit, the other to pasturelands and nomads who will take him in and shelter him 'according to their law' (p. 108). The prisoner looks at Daru with 'a sort of panic' but is told: 'No, be quiet. Now I'm leaving you' (p. 108). Daru turns and begins the long walk back toward the school. After turning and finding the prisoner still cemented to the spot where he'd left him, he curses impatiently, gives a vague waving motion, and, having walked some distance further, turns again. This time there is no one there. Daru now returns to where he'd left the prisoner, looks out to the east, and 'with a heavy heart', makes out the figure of the Arab walking slowly on the road toward the prison (p. 109). A little later, Daru, having returned to the school classroom, looks out over the plateau, with the blackboard behind him. On the blackboard are the words: 'You handed over our brother. You will pay for this' (p. 109). The story concludes: 'Daru looked at the sky, the plateau, and, beyond, the invisible lands stretching all the way to the sea. In this vast landscape he had loved so much, he was alone' (p. 109).

Much of the published work on the story has focused on the characters of Daru and the Arab, and on the latter's seemingly inexplicable decision to walk toward imprisonment despite an apparent opportunity to do otherwise. Daru has been variously portrayed as an existential hero, an agent of French oppression, or as 'something in between' (Muhlestein, 1999, p. 223). The prisoner has often been cast in a negative light, being described at different times as primitive, dim-witted or weak; his actions have been seen as barbarous, senseless and murderous (Griem, 1993, p. 95; Hurley, 1993, pp. 80, 88). He has, however, also sometimes been seen in more positive terms - as 'more intelligent and purposeful than he seems', taking responsibility for his actions (Showalter, 1984, p. 77). The relationship between Daru and the prisoner has been analysed in detail, and Balducci's role in the tale has also received some comment.

Somewhat surprisingly, given the focus on a school teacher and the setting of a classroom, the story has received little attention from educationists. A number of thinkers have considered the relevance of Camus's work for education (e.g., Denton, 1974; Gibbons \& Heraud, 2007; Götz, 1987; Oliver, 1973; Weddington, 2007), but these theorists have not addressed 'The Guest' as their main concern. Aidan CurzonHobson (2003) has published an insightful essay on Camus and empowering classroom relationships, with Exile and the Kingdom as the principal focus. His comments on 'The Guest' are, however, comparatively brief. One of the most detailed studies of the story from an educational point of view has been published not in a journal or book in the field of Education, but in the literary periodical Studies in Short Fiction. Daniel Muhlestein (1999) has applied an Althusserian framework in 
examining the story, drawing in particular on Althusser's (1971) well known distinction between 'Repressive State Apparatuses' (RSAs) and 'Ideological State Apparatuses' (ISAs).

This paper acknowledges the important contribution made by Muhlestein while also suggesting an alternative educational reading of Camus's story. The first section provides a brief summary of Muhlestein's account. In the second section, I identify what I see as weaknesses in Muhlestein's Althusserian interpretation and argue for a reading that better acknowledges the moral complexity of the three principal characters in the story: Daru, the prisoner and Balducci. 'The Guest', I hope to show, is of interest not only from an aesthetic point of view, but as a text relevant to the everyday ethical lives of teachers.

My interest in this paper lies not so much in the idea of the 'teacher in fiction' as in the educational insight that texts such as 'The Guest' can provide. It might be argued that Daru's position as a school teacher is largely incidental - that the same narrative effect could have been achieved had he been, say, a doctor (or a priest, or a counsellor, or a representative of any number of other professions). ${ }^{1}$ Such a claim would be at odds with what we know of Camus as a writer: he paid careful attention to detail in the development of his characters, choosing their names and roles deliberately and with care. He would have been well aware of the symbolic importance of the school classroom as a backdrop for the narrative and of the responsibilities specific to teachers in an Algerian desert setting. Yet, even if we accept that Daru could have occupied another professional role, this would affirm rather than diminish the educational importance of the text. For the point would be that all of us are potentially teachers. We become teachers through the way we interact with others, drawing on our knowledge and experience, and, in turn, learn from those we teach.

There is much that educationists might gain from studying fictional portraits of teachers. From Dickens' brilliant depiction of Gradgrind in Hard Times (Dickens, 2003), for instance, we can learn a great deal about the limits of a utilitarian, nothingbut-facts approach to teaching. A number of excellent studies of teachers in novels have been published (e.g., Furness, 1962; Katz, 1997; Laird, 1991). Literary works can also be helpful, however, in demonstrating how teaching and learning occur throughout our lives, whatever our profession or position in society. The well established German tradition of the Bildungsroman illustrates how learning and teaching can be explored and understood via the fictional portrait of a central character's growth and development (see Roberts, 2008a, 2008b; Swales, 1978). Teaching and learning are ethical activities, where judgements about what and whom to favour must be made across the educational lifespan. This paper takes this broader perspective on teaching and learning as its starting point in considering the educational significance of 'The Guest'.

\section{'The Guest': An Althusserian reading}

Muhlestein (1999) argues that Althusser's definition of the state (together with Stephen Greenblatt's theory of subversion and containment) allows us to 'come to grips with Daru's character, the prisoner's choice, and the causality that links the former to the latter' (p. 224). According to Althusser, the state has two types of apparatuses. The first, 'Repressive State Apparatuses' (RSAs), rely on force to impose the will of the state. RSAs include public institutions such as the government, 
the police and the army. The second type, 'Ideological State Apparatuses' (ISAs), propagate an ideology that transforms individuals into subjects of the state. Key ISAs are the family, the church and the school. Schools work to turn potentially unruly students into productive, obedient citizens, providing both the skills necessary for students to succeed in the workplace and an ideology appropriate to their place in the social order.

In Muhlestein's view, Daru 'proves himself to be an Ideological State Apparatus par excellence' (p. 224). As an educational ISA, Daru receives the support of the state and is expected, in turn, to teach his students French ideology. An example of this can be seen in the geography lesson, where French rivers are drawn on the blackboard. Algerian students thus learn not about their own country but about the colonial power of France. When Daru questions his role as an ISA, Balducci becomes a repressive agent of the state: he orders Daru to deliver the prisoner to police headquarters in Tinguit. The mechanism through which ideology works, in Althusserian theory, is ‘interpellation' or 'hailing'. By this Althusser means:

... something like "calling out to", "naming" or "giving an identity to" ... Hailing is accomplished through gesture and ritual as well as language and name. And in "The Guest" Balducci uses salutation ..., smile ..., ritual ..., and declaration ... to interpellate Daru as a friend and colleague, thereby paving the way for a final, more difficult hail: jailer. (p. 225)

Balducci also invokes the ISA of the family in trying to persuade Daru to become an RSA. He refers repeatedly to Daru as his son and, having established this surrogate family tie, is insulted when Daru objects to his requests. For Althusser, ideology will be backed up by force where necessary, and this is the case for Daru as well as Balducci. Daru confirms for Balducci that he has a shotgun if needed. Muhlestein elaborates:

The martial metaphor with which Daru describes his life as a teacher is thus surprisingly apt: "he had enough [provisions] to resist a siege" ... Teachers use an implicit threat of force, and the police try to "teach" criminals a "lesson". Teachers and policeman are two sides of the same state coin, and though they are different sides, they necessarily share a common center: state power and authority. (p. 227)

This story is set in a time of Algerian unrest, and Balducci reminds Daru that if there is an uprising, no one will be safe. Balducci and Daru both become symbols of colonisation. Daru at this point concedes to becoming an RSA, but on his own terms - agreeing to fight if has to but refusing to hand the prisoner over. Muhlestein argues, however, that Daru's subversion ultimately serves the state's purpose. Where acts of subversion occur in the story, all are contained. Daru, as a native of the Algerian desert, adheres to the code of hospitality common to desert peoples. As Daru undergoes the rituals associated with hosting a guest, serving tea and providing suitable sleeping arrangements, he begins to view the prisoner as a subject. 'The more fully Daru enacts the rituals of hospitality, the more they impose upon him "a sort of brotherhood" with the prisoner which he is both loath to accept and unable to fully reject' (p. 229). Balducci has left his revolver for Daru, but Daru rejects this hail, putting the gun in a desk drawer. His sense of honour as a host and his growing recognition of the prisoner's subjectivity leave Daru with little choice but to act, and he does so by giving the Arab food, money and a chance to shape his own destiny. But this, in the end, does not undermine the power of the state: 
In an obvious and important sense, ... Daru frees the prisoner. He subverts empire's most powerful ideological tool by acknowledging the Arab's subjectivity. And he undermines the repressive power of the colonial state by releasing the prisoner from physical bondage. Unfortunately, however, the same process of hailing the persuades Daru to free the prisoner insures that the prisoner will use that freedom to submit himself to the power of the state. As Althusser points out, a hail establishes a reciprocal relationship between subject and society, freedom and obedience. The hail grants the individual special status as a subject by identifying his or her place in society and defining the obligations and commitments that such placement entails. To retain that status, the individual must fulfill those obligations and commitments. (pp. 230-231)

\section{Muhlestein continues:}

Just as a host feeds, shelters, and protects a guest, so a guest reciprocates by the honorable way in which he or she accepts the proffered hospitality. And what guest, having been given food, shelter, protection, and freedom, can honorably exercise that freedom to the detriment of the host? Not this guest. Having accepted the rituals of hospitality, the Arab is now bound by its iron law. And, in this case, he is thereby bound for prison. Why? Because Daru is more than a simple desert host. He is also an agent of the state, a teacher, an Ideological State Apparatus. As such, he necessarily produces a binary hail. (p. 231)

Thus, by granting the prisoner a certain form of free subjecthood, Daru also binds him to the requirement for obedience that is common to all such subjects: the requirement 'to live in subjection to the state' (p. 231). To meet his obligations as a guest, the prisoner 'must acknowledge that hail and subject himself to the power of the state' (p. 232). Daru's acts of subversion thereby produce their own containment, and the prisoners takes himself to jail. The prisoner chooses prison over freedom 'because he must' (p. 232). Daru's heavy heartedness arises from his recognition that choice is overdetermined, and he watches the drama move 'inexorably towards its foregone conclusion' (p. 232). Daru may be a good man, but he is an even better teacher. Far from failing in his pedagogical role, Daru does exactly what is expected of him as an ideological agent of the state:

Daru teaches his pupils, and he teaches his guest. He teaches through hailing, and he teaches through hospitality. And in "The Guest", he teaches obedience through his refusal to obey, turning the prisoner's stay at the school into what Harold Bloom calls - in a very different context - a "Scene of Instruction". [...] In that sense, the writing on the chalkboard is precisely true: "You handed over our brother", the message declares. [...] And in fact, Daru has. And he has done so precisely by setting him free. (p. 232)

\section{An alternative perspective}

Muhlestein's analysis of 'The Guest' is rigorous, systematic and insightful. His Althusserian framework allows some of the tensions and contradictions that have remained in other readings to be explained or resolved. As one of the few commentators to pay detailed attention to pedagogical themes in the story - including the relationship between teacher and student, the role of the school in securing the aims of the state, and the process of learning - Muhlestein has made an important contribution not only to scholarship on Camus but to the field of education. His interpretation 'works': it provides a cohesive and coherent way of making sense of a complex and difficult tale from a master literary craftsman.

I want to suggest, however, that Muhlestein's Althusserian reading is too neat, too tidy and conclusive. The problem lies in the assumptions underpinning the theoretical 
framework Muhlestein has applied. Althusser's work is helpful in understanding the process of educational reproduction, but it also has its limits. As was recognised by Henry Giroux (1983), Michael Apple (1985), and other critical educationists in the 1980s, Althusser's account does not pay adequate attention to the forms of resistance that are often part of the reproduction process. It does not address the complexities of student (or teacher) subjectivity in sufficient detail, and it appears to reduce participants in the educational process to mere pawns in a larger repressive game. As Giroux (1983) points out, Althusser's theory is too one-sided; it views schools not as sites of both domination and struggle but as sites that 'function smoothly to reproduce a docile labor force' (p. 82). Ideology from an Althusserian perspective becomes an oppressive 'force', immune to effective criticism and the possibility of change.

\begin{abstract}
Althusser has developed a notion of power that appears to eliminate human agency. The notion that human beings are neither homogeneously constituted subjects nor passive role bearers is lost in Althusser's ... analysis. In effect, there is no theory of mediation in this perspective; nor is there any conception of how people appropriate, select, accommodate, or simply generate meaning. Instead, in Althusser's reductionist schema human beings are relegated to static rolebearers, carriers of pre-defined meanings, agents of hegemonic ideologies inscribed in their psyche like irremovable scars. (Giroux, 1983, pp. 82-83)
\end{abstract}

This sense of inevitability is conveyed clearly in Muhlestein's analysis of 'The Guest'. Note the language Muhlestein employs. The prisoner, having accepted Daru's hospitality, is 'bound by its iron law' (Muhlestein, 1999, p. 231). As an agent of the state, a teacher, Daru 'necessarily produces a binary hail' (p. 231, emphasis added). The Arab chooses prison over freedom 'because he must' (p. 232), and the events move 'inexorably' toward their 'foregone conclusion' (p. 232). On this account, there is no hope for any of the key characters in the story - no hope, that is, that events could be otherwise.

The Arab becomes a largely unreflective follower of tradition, unable, even in circumstances that will lead to his imprisonment and probable death, to question established customs or to consider how his current circumstances might differ from others involving reciprocal hospitality. We don't know what, exactly, the prisoner is thinking; Camus' narrative maintains one of its many silences on this point. The prisoner's thoughts can be inferred from his actions and gestures and responses, but this involves the application of an interpretive framework. In the moments leading up to the prisoner's decision, the text provides some clues to understanding his inner state, but these leave considerable scope for varying interpretations. At the point where Daru reaches the crumbly rocks, pauses, and surveys the two possible directions, the narrator says: 'He turned toward the Arab, who was looking at him blankly' (Camus, 1991, p. 107). When Daru gives the prisoner food and money, the latter keeps his hands at chest level, 'as if he didn't know what to do with what was being given him' (p. 107). When Daru lays out the options to the prisoner, '[t]he Arab had now turned toward Daru and a sort of panic was visible in his expression' (p. 108).

These quoted passages might seem, at first glance, to suggest a form of cognitive simplicity in the prisoner's thinking processes. Festa-McCormick (1988) contends that the prisoner "clearly does not understand the "existential" choice that confronts him' (p. 112). Closer examination, however, reveals a subtle shift. Where there is at first blankness - suggestive of incomprehension or a lack of any significant cognitive activity - this becomes perplexity and then panic. Perplexity need not be viewed in a negative light. It can be seen as a mental state that holds out the promise of more than 
one possible decision being made. Indeed, it can be regarded as an affirmation of human agency; of the capacity to make decisions, to act in ways that are, as Paulo Freire $(1998,2004)$ would put it, shaped or conditioned but not determined by ideology - by culture and tradition and the ideas of the dominant class. From this perspective, perplexity suggests it could be otherwise. The Arab could have walked toward the nomads instead of the prison; indeed, he could have taken other decisions, attempting, for example, to return with Daru. It is not obvious that Daru is in a position to physically force the prisoner to take any one path. The panic described in the third of three quoted passages suggests a more active inner state, a kind of emotional as well as cognitive turmoil generated by increased reflective activity. It is not clear whether the prisoner experiences panic because an apparent opportunity to choose has been given to him, or because of the options made available to him, or because of his sense of fear about the possible consequences of his decision for himself, Daru or others. Regardless, it is possible to interpret this passage in the text as an indication of a more active and complex inner life in the prisoner than Muhlestein's account allows. The prisoner can be seen as not just a follower of state dictates, through Daru's influence as a conveyer of state ideology, but as a being who engages in a brief but important process of moral deliberation, notwithstanding the seemingly barbaric nature of his earlier crimes.

In short, Muhlestein's Althusserian viewpoint denies the possibility of inner struggle - of psychological dissonance, internal conflict or emotional turmoil - as the basis on which the prisoner's decision is built; yet there is nothing in the story as presented that definitively rules this out. Social life is full of examples of difficult decisions, decisions seemingly against one's self-interests, being made after much agonising and inner strife. Women in situations of domestic violence, for example, will sometimes remain in such relationships, despite the obvious harm being inflicted, in serving what they see as the best interests of their children. The prisoner, on Muhlestein's account, is one-dimensionalised; he becomes simply a passive performer in a role that has already been decided for him by the workings of a repressive state ideology.

Daru, similarly, loses the capacity for genuine resistance. He emerges from Muhlestein's analysis as a more multilayered moral being than the prisoner, but despite this it appears as if any resistance he does offer merely reinforces the process of state domination. A connection might be made here with the work of Willis (1977) who, in his classic ethnography of schooling, found that the forms of resistance practised by one group within the school (the 'lads') ended up playing a significant part in reproducing the existing social relations of production. The lads, by resisting the dominant ideology via acts construed by their teachers as misbehaviour and laziness, achieved poor results in their schooling and ended up, in most cases, in the same sorts of factory jobs as their fathers. The attentive students who worked hard and did as they were told (the 'Ear'oles') succeeded in the schooling system and, like their fathers, could look forward to the prospect of jobs beyond factory walls. Daru resists a number of elements of state repression (his refusal to take the prisoner to the police station being the most obvious) but for Muhlestein all these acts of 'subversion' are ultimately contained - and, indeed, collectively contribute to the prisoner's fatal decision. It becomes a case, as in Willis' study, of reproduction through resistance rather than in spite of it.

For an Althusserian, Daru's role, as a teacher, is especially important in ensuring this process of reproduction takes place. In one sense, Daru teaches others (the prisoner, the prisoner's associates, Balducci and his colleagues) that acts of 
subversion do not pay - that they will ultimately be punished. In another sense, he shows that they do pay, but not in a way that might be easily recognised or comprehended. We can come to accept such forms of resistance as 'all we can do' in difficult circumstances, where there are no easy answers. Our sense of moral integrity remains intact, and state power continues to be exercised. Such a position would not be incompatible with an Althusserian reading of the story. Yet, this too denies human beings a certain moral complexity. It assumes that what has occurred is a straightforward process of reproduction - albeit via acts of subversion and containment rather than, say, the application of force through state brutality. This is not as self-evident as it seems. True, the prisoner walks towards confinement and probable death, but it might be surmised that he does not walk there the same man as he might have done without Daru's intervention. Both he and his 'brothers' might conceivably be seen as demonstrably altered by these events. The message on the blackboard, the origins of which are not explained in the story, hints at the possibility of further resistance, even if this is within the destructive mould of someone having to 'pay' for their actions.

Several different theories about the words on the blackboard have emerged over the years. It has most commonly been assumed that the message has been recorded by Arab tribesmen or by other rebels who regard Daru's actions as supportive of French colonial power. But it is also possible the words have been written by Daru's students (some of whom may feel a kinship with the prisoner) or by Daru himself, who may have reflected on his actions as a betrayal of a fellow human 'brother' (cf. Rooke, 1967; Simon, 1964). All of these possibilities suggest some form of significant change has occurred. Daru's actions as a teacher and host may have played a part in the prisoner's final decision, and he may return to his classroom (suggesting the process of reproducing state ideology will continue). But he will do so a different teacher, with experiences he could not have anticipated (and the knowledge gained through those experiences) having altered him for ever. All is not the same, following the events of the story, as it was before.

Balducci cannot be ignored here either. From an Althusserian point of view, he becomes, perhaps more transparently than Daru, an agent of the state. In Balducci's character and conduct, we can see both RSAs and ISAs in action, to use the Althusserian terms. As a gendarme, he represents the repressive power of the state, ready and willing to use force if necessary. Violence, Althusser (1971) argues, is at the heart of the Repressive State Apparatus (p. 138). At the same time, given the way he views Daru - as a kind of surrogate son - Balducci also becomes part of the Ideological State Apparatus of the family. There is, however, an alternative way to view his dual roles. Balducci can be seen not merely as a bearer of state ideology and repressive power but as a creator, with others, of conditions of moral complexity. Balducci is not merely an automaton carrying out his state duties; he is a man torn by different feelings and commitments. He has an affection for Daru, and Daru's resistance is hurtful: Balducci feels this as a personal insult, a breaking of the bond he believes he has established with the younger man. Nor is Balducci an unreflective enforcer of state power. His inner conflicts emerge more openly as Daru's steadfastness in resistance is confirmed. As if to reassure Daru that he is not merely an unthinking, unfeeling functionary for repressive state power, Balducci says: 'I don't like it either. You don't get used to putting a rope on a man even after years of it, and you're even ashamed - yes, ashamed' (Camus, 1991, p. 95). At the same time, he feels a duty to uphold a sense of order, adding: 'But you can't let them get their own way’ (p. 95). These words are not uttered with uncontrolled anger, but with care 
and thought. He makes his comments 'slowly', the text indicates (p. 95). When Daru remains firm in his resolve not to hand over the prisoner, Balducci makes 'a visible effort to reflect' (p. 95). He looks at both Daru and the Arab, taking some time before making his decision. And that decision is by no means a simple compliance with his (in Althusserian terms, repressive) state duties. Faced with a moral dilemma, Balducci reaches a compromise, gaining the signature he needs, while also resisting state power with his commitment not to tell the authorities or to denounce Daru.

If we grant the prisoner, Daru and Balducci a moral complexity that appears to be denied them by an Althusserian account of their decisions and actions, what does this suggest for an understanding of the text, and for its educational implications in particular? Certainly judgements of the kind offered by English Showalter (1984) that '[t]he Arab is not a puzzle we are meant to solve but rather a blank, eternally, irrevocably meaningless' (p. 85) - must, I think, be rejected. Showalter premises this claim on a connection he sees between the Arab and the physical environment in the story:

\footnotetext{
The Arab belongs to that eternal cycle, like the stones cracking in the sun, the stinging wind, the tireless waves, the wheeling stars, motifs that recur in almost every story [in Exile and the Kingdom]. The Arab is just someone who passes by. His actions - the murder, his words to Daru, his staying at the school, his taking the road to Tinguit - signify no more than do the changes in the weather. If a mind and soul inhabit that body, they stay as unrecognizable as the mind and soul of the material universe. (p. 85)
}

This seems to me to rob the prisoner of his humanity. The prisoner becomes little more than an organic object. He is, on this view, denied his status as a thinking, feeling and willing human being. He does not deliberate, question, or suffer; he simply exists. To be fair to Showalter, there are quite explicit passages in the text that appear to lend weight to this interpretation. Little is said about Daru's physical characteristics (or Balducci's), but the Arab's features are described in some detail. Daru notices his 'huge lips, fat, smooth, almost Negroid' (Camus, 1991, p. 90). The Arab has an 'obstinate forehead', 'weathered skin', and 'feverish eyes' (pp. 90-91). Importantly, however, these are Daru's observations, and the reader is granted an opportunity, as the story unfolds, to consider them critically: to ask why such physical features have stood out for him, and to assess their relationship to Daru's unstated ontological and ethical assumptions about the prisoner. The very fact that we never learn the prisoner's name - he is simply 'the Arab' - might seem to push the reader rather aggressively in one direction, encouraging us to believe the narrator wants us to take on a dehumanising view. But, as Beer (2002) points out, the place of the narrator in the story also warrants critical examination: 'the third-person narrator figure can be seen to play a crucial role in the sequencing of proximity and distance, approach and retreat, centring and decentring that underpins the characters' interaction' (p. 181).

No one in 'The Guest' is entirely reliable as a witness to the Other - not Daru, not Balducci, not the prisoner, nor even the omniscient narrator - but this, in part, is what gives the story its ethical power. Hurley's (1993) caution against taking on, even if unconsciously, Daru's stance toward the prisoner, and through this regarding the latter as 'not rational, not ethical - not "us"' (p. 91) is worth heeding, but this too, if we are not careful, can have the effect of one-dimensionalising Daru. For there is much in Daru's conduct, as the story progresses, that acknowledges the prisoner's status as a complex moral being. Daru's view of the prisoner has been shaped by his culture, his experience as a teacher, and the politics of French colonialism, but, equally, the prisoner has been shaped by his traditions, customs, relationships, and commitments. 
Daru does not simply position the prisoner as an unknowable, unknowing 'Other' and denude him of his humanity; his kindnesses are more than mere ritual, given grudgingly as part of established tradition for any host. He puts himself at tremendous risk with his actions. Balducci advises Daru to do as asked and then to return to his students and his 'comfortable life' (Camus, 1991, p. 92). Following the events depicted in the story, it is clear that Daru's life is hardly likely to be 'comfortable', and there is every probability it never was.

'The Guest', like most of Camus' work, has been crafted with great care. Every word carries weight, and what is not said is also of considerable importance from an educational point of view. For the silences in the text prompt us, as readers, to ponder: Why did Daru (or the prisoner, or Balducci) act this way? Could it have been otherwise? What might the consequences of these actions be? The story, in this way, teaches us: it encourages a form of reflection that is often missing in our encounters with more didactic texts (cf. Roberts, 2008c). Camus does not preach to us; he lets the words, actions, gestures, relationships, and silences of his characters - and the symbolism of the setting - create the conditions for us to make up our own minds. This is no small point, for it speaks to the very process I am suggesting the characters themselves undergo: a form of complex ethical decision making in a situation where there is no easy way out for any of them.

All three of the principal characters face moral dilemmas. Daru's situation is of special interest to educators, many of whom are faced with problems similar in complexity, if not exactly in kind, to those encountered by Daru in the story. We often find ourselves in situations where adhering to one set of ideals will mean compromising another. We may, for example, be opposed to the competitive ethos engendered by the grading of student assignments, yet also not wish to disadvantage students as they seek to gain meaningful employment from their scholarly labours. Or, we may find we cannot support one colleague in a dispute while retaining the friendship and respect of another. Our commitment to our families may suffer in the face of doing all that is necessary to meet professional obligations. 'The Guest' does not provide a set of moral rules or prescriptives, and neither does the everyday life of most educators - whether in schools, universities, or other pedagogical settings. We have to make difficult decisions, and thereby confirm our ontological status as ethical beings, in educational situations that are often characterised by their 'messiness' rather than simplicity. If, when faced with such difficult circumstances, we attempt to avoid making decisions, we, in effect, make a decision to allow the status quo or the dominant views of others to prevail. There is no way to be 'neutral' as a teacher.

Daru has sometimes been criticised for attempting to do just that - to avoid committing himself at the very moments when ethical decisions carry most weight. Festa-McCormick (1988) argues that while Daru is portrayed in a sympathetic light by Camus, 'that does not diminish the fact that he has betrayed his mission as teacher by not conveying to the young criminal the importance and inviolability of freedom, by not attempting to communicate, either in pedagogical or in human terms, abhorrence against murder and prison alike' (p. 113). Accordingly, Daru stands condemned, '[t]rapped in his own alienation in a land he loves but that rebuffs him' (p. 113). For Thody (1964), '[i]f the story has any message, it is an appeal for understanding and tolerance on all sides' (p. 192). Yet, sometimes this is either not possible or not enough. Camus found himself torn over the Algerian situation in the 1950s, and attracted criticism from a number of other intellectuals - notably, JeanPaul Sartre - for his stance on the conflict (see Todd, 2000.) Daru also faces a dilemma: it is 'that of the many French residents in Algeria who are unable to bear 
violence, unable to ally themselves with either side, but unable to live elsewhere than in the country where they were born and have made their home' (p. 192). Adele King (1964) comments further:

'L'Hôte' expresses, indirectly, the tragedy of the Algerian political situation; violence was
prevalent on both sides, and both sides demanded complete allegiance from their followers.
Daru, who cannot give such allegiance, is faced with a dilemma similar to Camus's. Like
Camus, Daru finds only a painfully solitary course of action that seems to be a way of avoiding
responsibility. (p. 100)

Charges of avoiding responsibility, levelled against either Camus or Daru, may seem harsh, but there is perhaps a message here for all educationists. It is not enough, Festa-McCormick seems to imply, for teachers simply to lead students to the point where different paths can be taken (in the prisoner's case, these are literal as well as figurative paths); rather, teachers must take responsibility for describing in some detail what those options might entail. There is a fine balance here, though, between providing sufficient guidance to enable well-informed decision-making and 'steering' of a kind that works actively against the possibility of relative student freedom. A student, it might be said, must have a reasonable opportunity to make moral choices other than those preferred by the teacher. Camus has clearly been sensitive to this tension in the construction of his story, providing sufficient textual detail to enable reflection on the ethical decisions made by the key characters while, at the same time, avoiding authorial judgements that might push the reader too strongly in any one direction. Camus, while not pretending to be neutral, grants his readers a certain freedom to make ethical decisions of their own.

Camus has chosen even the title of his story with typical care. 'L'Hôte' can mean both 'guest' and 'host' (Cervo, 1990, p. 222; Simon, 1964, p. 289). Lazere's (1973) remarks on the multiple possible meanings in the story's title are revealing:

When Justin O’Brien was translating ... "L’Hôte”, he wrote to Camus asking whether to use the title "The Host" or "The Guest". Camus opted for the latter but added that it was a pity the ambiguity was lost in translation. "Host" has no less than three Latin origins: in addition to the root of its sense as the eucharistic host, hostia - "victim" or "sacrifice", there is hostis "stranger" or "enemy", and its compounded form hospes - "friendly stranger", either as guest or host. Is "I'hôte" Daru or the Arab, or perhaps both? Each man is at the same time friendly stranger, victim, and enemy. (p. 205) ${ }^{2}$

Both 'guests' and 'hosts': this is what we are as teachers in any formal or informal classroom setting. As the years go by, we 'host' many students who become 'guests' in our pedagogical 'home' for different periods of our lives. Like Daru, we have a range of professional and pedagogical responsibilities to meet. Students, too, have obligations, as was the case with the prisoner in the story. These are not limited to the completion of required assessment tasks, or to compliance with the rules and regulations of the institution. We typically hope, at least, that the effort we put into teaching will, at some stage in students' lives, be appreciated - even if only indirectly - and 'repaid' by what those students are able to pass on to others.

But we are also, in an important way, 'guests' in our own classrooms. Althusser is correct, I believe, in arguing that educational institutions such as schools play a significant role in perpetuating dominant ideas - ideas that serve the economic interests of a few while denying much to many. There is a very substantial body of empirical and theoretical work in the sociology of education supportive of this view. But the way in which this process of domination occurs is more complicated than 
Althusser's account would seem to suggest. The state may set limits on what becomes possible in, say, a school classroom - e.g., by imposing a compulsory curriculum, by making attendance compulsory, by having systems of school inspections - but it can never completely determine the nature of a pedagogical relationship between a teacher and the students with whom he or she works. There is always some space in an educational situation for creativity, difference and resistance. This being the case, the teacher is always a 'guest' of the students. The teacher must relearn the subject matter, even if in only subtle ways, every time he or she begins a new year or a new course. Students, as theorists such as Freire have long recognised (e.g., Freire, 1972), also teach their teachers - and this creates a pedagogical space where freedom, but freedom with limits, exists, no matter how repressive a state ideology may be. There is an unpredictability to the educational process that rubs against the certainties of an Althusserian position on the relationship between the state and the school. This is present in 'The Guest', and it is a testament to the power of Camus' storytelling that the reader can re-experience this, in different ways, with each reading of the text. The decisions made and the actions taken by Daru, Balducci and the prisoner are not inevitable and the story contains within its tensions, contradictions and dilemmas a range of alternative scenarios.

\section{Conclusion}

I started this paper by noting that 'The Guest' is a story rich with possibilities for multiple readings. Two such readings have been provided: the first, Muhlestein's Althusserian analysis of the text; and the second, an alternative interpretation centred on the moral complexity of the three principal characters. In both cases, the focus has been on educational themes. There is, of course, much more that could be said about the text, both from an educational point of view and from other perspectives. Other approaches include those with an emphasis on politics and French-Algerian colonial relations (Grimaud, 1992; Vulor, 2000), the psychological structure of the story (Grobe, 1966), questions of subjectivity and 'Otherness' (Beer, 2002), and the depiction of solitude and absurdity in the text (McGregor, 1997). This is by no means an exhaustive list. Camus, I think, would not want us to make quick and comfortable judgements about Daru, Balducci or the prisoner. 'The Guest' prompts us to keep thinking about the characters long after we have read the story, and to return to them again and again in seeking to better understand their thoughts, feelings and actions. In doing so, we open up opportunities to explore our own pedagogical decisions, commitments and relationships in a fresh light. For this reason, among others, 'The Guest' can be seen as a story worthy of continuing engagement by educationists.

\section{Acknowledgements}

I wish to thank the Editor and the anonymous reviewers for their helpful comments on the original manuscript.

\section{Notes}

1. I am indebted to the Editor and one of the anonymous reviewers for prompting clarification on this point. 
2. Important links might be made here with Derrida’s approach to hospitality (e.g., Derrida, 2000). For a helpful discussion of the relationship between 'guest' and 'host' in Derrida's account of hospitality, see Westmoreland (2008). I am grateful to one of the anonymous reviewers for alerting me to the possibility of further work in this area.

\section{References}

Althusser, L. (1971) Ideology and ideological state apparatuses, in Lenin and Philosophy and Other Essays, trans. B. Brewster (London, New Left Books), 123-186.

Apple, M. (1985) Education and Power (Boston, MA, Ark).

Camus, A. (1991) Exile and the Kingdom, trans. J. O’Brien (New York, Vintage International).

Camus, A. (2000) The Fall, trans. J. O’Brien (London, Penguin).

Cervo, N. (1990) Camus's L’Hote, Explicator, 48 (3), 222-224.

Curzon-Hobson, A. (2003) Between exile and the kingdom: Albert Camus and empowering classroom relationships, Educational Philosophy and Theory, 35 (4), 367-380.

Denton, D.E. (1964) Albert Camus: philosopher of moral concern, Educational Theory, 14, 99-127.

Derrida, J. (2000) Of Hospitality, trans. R. Bowlby (Stanford, Stanford University Press).

Dickens, C. (2003) Hard Times, revised edn., ed. K. Flint (London, Penguin).

Festa-McCormick, D. (1988) Existential exile and a glimpse of the kingdom, in: B.L. Knapp (ed.) Critical Essays on Albert Camus (Boston, Hall), 107-116.

Freire, P. (1972) Pedagogy of the Oppressed (Harmondsworth, Penguin).

Freire, P. (1998) Pedagogy of Freedom (Lanham, MD, Rowman and Littlefield).

Freire, P. (2004) Pedagogy of Indignation (Boulder, CO, Paradigm).

Furness, E.L. (1962) Portrait of the pedagogue in Eighteenth Century England, History of Education Quarterly, 2 (1), 62-70.

Gibbons, A. \& Heraud, R. (2007) Creativity, enterprise and the absurd: education and the Myth of Sisyphus - a challenge to an educator, paper presented at the Philosophy of Education Society of Australasia conference, Wellington, 6-9 December.

Giroux, H.A. (1983) Theory and Resistance in Education (South Hadley, MA, Bergin and Garvey).

Götz, I.L. (1987) Camus and the art of teaching, Educational Theory, 37 (3), 265-276.

Griem, E. (1993) Albert Camus's 'The Guest': a new look at the prisoner, Studies in Short Fiction, 30, 95-98.

Grimaud, M. (1992) Humanism and the ‘white man’s burden': Camus, Daru, Meursault, and the Arabs, in: A. King (ed.) Camus’s L’Etranger: Fifty Years On (New York, St Martin’s), 170-182.

Grobe, E.P. (1966) The psychological structure of Camus's 'L'Hôte', The French Review, 40 (3), $357-$ 367.

Hurley, D.F. (1993) Looking for the Arab: reading the readings of Camus's 'The Guest', Studies in Short Fiction, 30, 79-93.

Katz, M. (1997) On becoming a teacher: May Sarton’s The Small Room, Philosophy of Education 1997 (Urbana-Champaign, IL, Philosophy of Education Society). Retrieved 29 October 2001 from: http://w3.ed.uiuc.edu/EPS/PES-Yearbook/97_docs/katz.html

King, A. (1964) Camus (Edinburgh, Oliver and Boyd).

Laird, S. (1991) The ideal of the educated teacher - 'Reclaiming a conversation' with Louisa May Alcott, Curriculum Inquiry, 21 (3), 271-297.

Lazere, D. (1973) The Unique Creation of Albert Camus (New Haven, Yale University Press).

McGregor, R.R. (1997) Camus’s 'The Silent Men' and 'The Guest': depictions of absurd awareness, Studies in Short Fiction, 34, 307-321.

Muhlestein, D.K. (1999) A teacher and his student: subversion and containment in Camus's 'The Guest', Studies in Short Fiction, 36 (3), 223-234.

Oliver, T. (1973) Camus, man, and education, Educational Theory, 23 (3), 224-229.

Perrine, L. (1963) Camus' 'The Guest': a subtle and difficult story, Studies in Short Fiction, 1 (1), 5258.

Roberts, P. (2008a) More than a metaphor: the education of Joseph Knecht, Pedagogy, Culture and Society, 16 (2), 173-185.

Roberts, P. (2008b, in press) From West to East and back again: faith, doubt and education in Hermann Hesse's later work, Journal of Philosophy of Education, 42 (2).

Roberts, P. (2008c, in press) Bridging literary and philosophical genres: judgement, reflection and education in Camus’ The Fall, Educational Philosophy and Theory, 40 (2). 
Rooke, C. (1967) Camus' 'The Guest': the message on the blackboard, Studies in Short Fiction, 4, 7881.

Showalter, E., Jr. (1984) Exiles and Strangers: A Reading of Camus's Exile and the Kingdom (Columbus, Ohio State University Press).

Simon, J.K. (1964) Camus' kingdom: the native host and an unwanted guest, Studies in Short Fiction, 1 (4), 289-291.

Swales, M. (1978) The German Bildungsroman from Wieland to Hesse (Princeton, N.J., Princeton University Press).

Thody, P. (1964) Albert Camus, 1913-60 (London, Hamish Hamilton).

Todd, O. (2000) Albert Camus: A Life, trans. B. Ivry (New York, Carroll \& Graf).

Vulor, E.C. (2000) Colonial and Anti-Colonial Discourses: Albert Camus and Algeria (Lanham, MD, University Press of America).

Weddington, H.S. (2007) The education of Sisyphus: absurdity, educative transformation, and suicide, Journal of Transformative Education, 5 (2), 119-133.

Westmoreland, M.W. (2008) Interruptions: Derrida and hospitality, Kritike, 2 (1), 1-10.

Willis, P. (1977) Learning to Labour: How Working Class Kids Get Working Class Jobs (Farnborough, Saxon House). 